\title{
Anticancer, antioxidant activities, and DNA affinity of novel monocationic bithiophenes and analogues
}

This article was published in the following Dove Press journal:

Drug Design, Development and Therapy

29 September 2014

Number of times this article has been viewed

\author{
Mohamed A Ismail ${ }^{1,2}$ \\ Reem K Arafa ${ }^{3}$ \\ Magdy M Youssef ${ }^{\prime, 2}$ \\ Wael M El-Sayed ${ }^{1,4}$ \\ 'Departments of Chemistry and \\ Biological Sciences, College of \\ Science, King Faisal University, \\ Hofuf, Saudi Arabia; ${ }^{2}$ Department \\ of Chemistry, Faculty of Science, \\ Mansoura University, Mansoura, \\ Egypt; ${ }^{3}$ Department of Pharmaceutical \\ Chemistry, Faculty of Pharmacy, Cairo \\ University, Cairo, Egypt; ${ }^{4}$ Department \\ of Zoology, Faculty of Science, \\ University of Ain Shams, Abbassia, \\ Cairo, Egypt
}

Abstract: A series of 15 monocationic bithiophenes and isosteres were prepared and subjected to in vitro antiproliferative screening using the full National Cancer Institute (NCI)-60 cell line panel, representing nine types of cancer. Among the nine types of cancer involved in a fivedose screen, non-small cell lung and breast cancer cell lines were the most responsive to the antiproliferative effect of the tested compounds, especially cell lines A549/ATCC, NCI-H322M, and NCI-H460, whereas compounds 1a, 1c, 1d, and 7 exhibited potent activity, with GI $_{50}$ values (drug concentration that causes 50\% inhibition of cell growth) from less than $10 \mathrm{nM}$ to $102 \mathrm{nM}$. In addition, compounds $1 \mathrm{c}$ and $1 \mathrm{~d}$ gave $\mathrm{GI}_{50}$ values of $73 \mathrm{nM}$ and $79 \mathrm{nM}$, respectively, against the MDA-MB-468 breast cancer cell line. Structure-activity relationship findings indicated that the mononitriles were far less active than their corresponding monoamidines and, within the amidines series, the bioisosteric replacement of a thiophene ring by a furan led to a reduction in antiproliferative activity. Also, molecular manipulations, involving substitution on the phenyl ring, or its replacement by a pyridyl, or alteration of the position of the amidine group, led to significant alteration in antiproliferative activity. On the other hand, DNA studies demonstrated that these monoamidine bichalcophenes have promising ability to cleave the genomic DNA. These monoamidines show a wide range of DNA affinities, as judged from their DNA cleavage effect, which are remarkably sensitive to all kinds of structural modifications. Finally, the novel bichalcophenes were tested for their antioxidant property by the ABTS (2,2'-azinobis(3-ethylbenzthiazoline-6-sulfonic acid) diammonium salt) assay, as well as lipid and nitric oxide scavenging techniques, and were found to exhibit good-to-potent antioxidant abilities.

Keywords: bithiophenes, anticancer, DNA cleavage, antioxidant, Suzuki coupling, Stille coupling

\section{Introduction}

According to a recent report by the World Health Organization, there are now more than 10 million cases of cancer per year worldwide. Statistics from the American Cancer Society showed that cancer is the third most lethal disease after cardiovascular diseases and infectious and parasitic diseases. ${ }^{1-4}$ Cancer refers to a diversity of diseases, characterized by the uncontrolled proliferation of cells into a different form, against the normal complement of the organism..$^{5}$ The continuous proliferation of cancer cells develops into tumor tissues and may spread across to other organs. The principal need in the chemoprevention of cancer remains the discovery of new agents that are effective and safe.

Sulfur-containing molecules are of particular interest, being widely spread in nature. For example, diallyldisulfide, found in garlic, appears to be potent in protecting against skin, colon, and lung cancer. ${ }^{6-8}$ Also, biotin, known as vitamin B7, contains a tetrahydrothiazole ring as an integral part of its structure and acts as an essential cofactor in integral biological metabolic pathways, such as gluconeogenesis, fatty acid synthesis, and amino acid anabolism. ${ }^{9}$ Bithiophenes and oligothiophenes and their derivatives are important synthetic
Correspondence: Mohamed A Ismail Department of Chemistry, College of Science, King Faisal University, PO Box 380, Hofuf 31982, Saudi Arabia Tel +966533543735

Email mabouelenan@kfu.edu.sa
Drug Design, Development and Therapy 20।4:8 1659-1672 (c) (i) (5) 2014 Ismail et al. This work is published by Dove Medical Press Limited, and licensed under Creative Commons Attribution - Non Commercial (unported, v3.0) BY NC License. The full terms of the License are available at http://creativecommons.org/licenses//by-nc/3.0/. Non-commercial uses of the work are permitted without any further permission from Dove Medical Press Limited, provided the work is properly attributed. Permissions beyond the scope of the License are administered by Dove Medical Press Limited. Information on
how to request permission may be found at: http://www.dovepress.com/permissions.php 
precursors for biologically active materials. ${ }^{10-13}$ Oligothiophene compound $\alpha$-terthienyl (I) (Figure 1) is considered an antiinfective, antiviral, and photosensitizing agent. ${ }^{14,15}$

A number of compounds in this class of aromatic cationic molecules have been shown to bind to the minor groove of DNA at AT-rich sites, and the details of their interaction with the minor groove have been elucidated from biophysical studies, ${ }^{16-19}$ including crystal structures. ${ }^{20-22}$ It is hypothesized that these types of molecules exert their biological activity by first binding to DNA and then by inhibiting one or more of several DNA-dependent enzymes, or perhaps by direct inhibition of transcription. ${ }^{23,24}$ Recently, bithiophene diamidines (II) showed good DNA binding affinity and potent antiprotozoal activity, ${ }^{10}$ whereas, a symmetrical diamidinophenylbithiophene (III) exhibited cellular activity by binding to DNA and inhibiting binding of erythroblast transformation-specific (ETS)-related gene, an ETS family transcription factor that is commonly overexpressed or translocated in leukemia and prostate cancer. ${ }^{25,26}$ Although thiophene and furan rings are known for their broad biological activities, ${ }^{27}$ we have shown that replacing one or more furan ring with a thiophene one increased the DNA binding affinity, ${ }^{10}$ antibacterial, and antioxidant activities. ${ }^{11,28}$

Cancer occurs when genetic mutations accumulate in cells during the replication of genetic material, allowing cells to undergo transformation. Recently, a promising antimutagenic activity against sodium azide and benzo[a]pyrene-induced mutagenicity was shown for many of fluorinated and nonfluorinated bichalcophenes..$^{29,30}$ In particular, monocationic bithiophene (IV) has the highest antimutagenic activity, which is superior to other tested bichalcophenes. ${ }^{29}$

As part of a research program directed toward the discovery of anticancer drugs, and due to the importance of bithiophenes and oligothiophenes as therapeutic agents, and their unusual DNA binding affinity, we have decided to synthesize new isosteres of compound IV, which showed potent

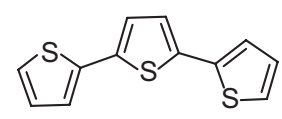

I

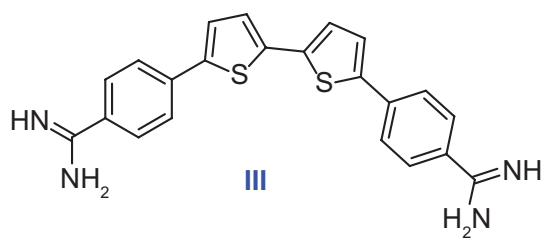

anticancer activity, by changing the location of the amidine group to be attached directly to the bithiophene moiety. Modifications have also included the replacement of a phenyl ring with 4-methoxyphenyl, 3,5-dimethoxyphenyl, and thiophene units. In this report, DNA cleavage and antioxidant activity testing results of the prepared series of cationic bithiophenes and analogues have also been reported and discussed.

\section{Experimental methods Chemistry}

Melting points (mps) were recorded using a Gallenkamp melting-point apparatus and were uncorrected. Thin-layer chromatography analysis was carried out on silica gel $60 \mathrm{~F}_{254}$ precoated aluminum sheets and detected under ultraviolet (UV) light. Infrared spectra were recorded using a KBr wafer technique on a Shimadzu 5,800 Fourier transform infrared spectrometer. ${ }^{1} \mathrm{H}$ and ${ }^{13} \mathrm{C}$ nuclear magnetic resonance (NMR) spectra were recorded using a Varian Mercury VX 300 spectrometer and a Bruker Avance $400 \mathrm{MHz}$ spectrometer, and chemical shifts $(\delta)$ were in parts per million, relative to tetramethylsilane as an internal standard. Mass spectra were recorded on a gas chromatography mass spectrometer (Shimadzu GPMS-QP2010 Plus). Elemental analyses were performed using a PerkinElmer 2,400 analyzer at the microanalytical laboratories of the Faculty of Science, Cairo University, and were within \pm 0.4 of the theoretical values (Table 1). All chemicals and solvents were purchased from Sigma-Aldrich Chemical Company and Thermo Fisher Scientific.

\section{General procedure for preparation of mononitrile bithiophenes $4 a-4 c$}

$5^{\prime}$-phenyl-2,2' -bithiophene-5-carbonitrile (4a)

To a stirred solution of $5^{\prime}$-bromo-2,2'-bithiophene-5carbonitrile (2.7 g, $10 \mathrm{mmol})$ and tetrakis(triphenylphosphine) palladium $(190 \mathrm{mg})$ in toluene $(20 \mathrm{~mL}), 10 \mathrm{~mL}$ of a 1.5 $\mathrm{M}$ aqueous solution of $\mathrm{NaHCO}_{3}$ was added, followed by<smiles>N=C(N)c1ccc(-c2ccc(-c3ccc(C(=N)N)s3)s2)cc1</smiles>

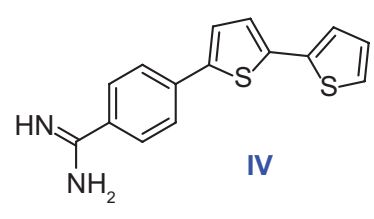

Figure I Biologically important thiophene-based structures. 
Table I Elemental analysis

\begin{tabular}{|c|c|c|c|c|c|c|}
\hline \multirow[t]{2}{*}{ Compound } & \multicolumn{3}{|c|}{ Calculated } & \multicolumn{3}{|c|}{ Found } \\
\hline & C & $\mathbf{H}$ & $\mathbf{N}$ & C & $\mathbf{H}$ & $\mathbf{N}$ \\
\hline 4a $\left(\mathrm{C}_{15} \mathrm{H}_{9} \mathrm{NS}_{2}\right)$ & 67.38 & 3.39 & 5.24 & 67.25 & 3.50 & 5.09 \\
\hline $4 \mathrm{~b}\left(\mathrm{C}_{16} \mathrm{H}_{11} \mathrm{NOS}_{2}\right)$ & 64.62 & 3.73 & 4.71 & 64.28 & 3.67 & 4.79 \\
\hline $4 \mathrm{c}\left(\mathrm{C}_{17} \mathrm{H}_{13} \mathrm{NO}_{2} \mathrm{~S}_{2}\right)$ & 62.36 & 4.00 & 4.28 & 62.42 & 3.79 & 4.35 \\
\hline $6\left(\mathrm{C}_{13} \mathrm{H}_{7} \mathrm{NS}_{3}\right)$ & 57.11 & 2.58 & 5.12 & 57.06 & 2.49 & 4.83 \\
\hline $5 \mathrm{a}\left(\mathrm{C}_{15} \mathrm{H}_{12} \mathrm{~N}_{2} \mathrm{~S}_{2}-\mathrm{I} .0 \mathrm{HCl}-\mathrm{I} . \mathrm{I} \mathrm{H}_{2} \mathrm{O}\right)$ & 52.88 & 4.49 & 8.22 & 52.71 & 4.68 & 8.16 \\
\hline $5 \mathrm{~b}\left(\mathrm{C}_{16} \mathrm{H}_{14} \mathrm{~N}_{2} \mathrm{OS}_{2}-\mathrm{I} .0 \mathrm{HCl}-\mathrm{I} .5 \mathrm{H}_{2} \mathrm{O}\right)$ & 50.85 & 4.80 & 7.41 & 50.89 & 4.73 & 7.74 \\
\hline $5 \mathrm{c}\left(\mathrm{C}_{17} \mathrm{H}_{16} \mathrm{~N}_{2} \mathrm{O}_{2} \mathrm{~S}_{2}-1.0 \mathrm{HCl}-1.4 \mathrm{H}_{2} \mathrm{O}\right)$ & 50.27 & 4.91 & 6.90 & 49.99 & 4.74 & 7.16 \\
\hline $7\left(\mathrm{C}_{13} \mathrm{H}_{10} \mathrm{~N}_{2} \mathrm{~S}_{3}-\mathrm{I} .0 \mathrm{HCl}-\mathrm{I} .25 \mathrm{H}_{2} \mathrm{O}\right)$ & 44.68 & 3.89 & 8.02 & 44.84 & 3.97 & 7.77 \\
\hline
\end{tabular}

phenylboronic acid (1.46 g, $12 \mathrm{mmol})$ in $5 \mathrm{~mL}$ of methanol. The vigorously stirred mixture was warmed to $80^{\circ} \mathrm{C}$ for 16 hours. The product was extracted with ethyl acetate $(250 \mathrm{~mL}, 3 \times)$. The organic layer was passed through celite to remove palladium, dried $\left(\mathrm{Na}_{2} \mathrm{SO}_{4}\right)$, and then concentrated to dryness under reduced pressure, to afford the mononitrile $4 \mathrm{a}$ in $78 \%$ yield, $\mathrm{mp} 133^{\circ} \mathrm{C}-134^{\circ} \mathrm{C}(\mathrm{EtOH}) . \mathrm{R}_{\mathrm{f}}=0.69$, petroleum ether $\left(60^{\circ} \mathrm{C}-80^{\circ} \mathrm{C}\right)$-EtOAc (8:2). IR ( $\left.\mathrm{KBr}\right) v^{\prime} 3,093,3,021$ $(\mathrm{CH}), 2,216(\mathrm{CN}), 1,610,1,594,1,581(\mathrm{C}=\mathrm{C}) \mathrm{cm}^{-1} .{ }^{1} \mathrm{H} \mathrm{NMR}$ (DMSO- $\left.d_{6}\right) ; \delta 7.35-7.59(\mathrm{~m}, 6 \mathrm{H}), 7.69-7.72(\mathrm{~m}, 2 \mathrm{H}), 7.96(\mathrm{~d}$, $\mathrm{J}=4.5 \mathrm{~Hz}, 1 \mathrm{H}$ ). MS (EI) $\mathrm{m} / \mathrm{e}$ (relative intensity [rel int]); 267 ( $\left.\mathrm{M}^{+}, 100\right), 233$ (21). 152 (41). Analysis $\left(\mathrm{C}_{15} \mathrm{H}_{9} \mathrm{NS}_{2}\right) \mathrm{C}, \mathrm{H}, \mathrm{N}$.

5'-(4-methoxyphenyl)-2,2'-bithiophene-5-carbonitrile (4b) A yellow solid in $81 \%$ yield, $\mathrm{R}_{\mathrm{f}}=0.48$, petroleum ether $\left(60^{\circ} \mathrm{C}-80^{\circ} \mathrm{C}\right)$-EtOAc $(8: 2), \mathrm{mp} 154^{\circ} \mathrm{C}-155^{\circ} \mathrm{C}(\mathrm{EtOH} / \mathrm{DMF})$. IR (KBr) v' 3,089, 2,966, 2,938 (CH), 2,217 (CN), 1,603, 1,594, $1,570(\mathrm{C}=\mathrm{C}) \mathrm{cm}^{-1} .{ }^{1} \mathrm{H}$ NMR (DMSO- $\left.d_{6}\right) ; \delta 3.76$ (s, 3H), 6.98 (d, J=8.4 Hz, 2H), 7.43-7.46 (m, 2H), 7.51 (d, $\mathrm{J}=3.8 \mathrm{~Hz}, 1 \mathrm{H}), 7.62$ (d, J=8.4 Hz, 2H), 7.92 (d, J=4.5 Hz, 1H). MS (EI) m/e ([rel int]); 297 (M+1 100), 282 (73), 254 (25). Analysis $\left(\mathrm{C}_{16} \mathrm{H}_{11} \mathrm{NOS}_{2}\right) \mathrm{C}, \mathrm{H}, \mathrm{N}$.

\section{5'-(3,5-dimethoxyphenyl)-2,2'-bithiophene- \\ 5-carbonitrile (4c)}

A yellow solid in $76 \%$ yield, mp $160^{\circ} \mathrm{C}-161^{\circ} \mathrm{C}(\mathrm{EtOH} /$ DMF). $\mathrm{R}_{\mathrm{f}}=0.42$, petroleum ether $\left(60^{\circ} \mathrm{C}-80^{\circ} \mathrm{C}\right)$ - $\operatorname{EtOAc}(8: 2)$. IR (KBr) v' 3,097, 3,065, 2,993, 2,940 (CH), 2,214 (CN), 1,585, 1,551 $(\mathrm{C}=\mathrm{C}) \mathrm{cm}^{-1} .{ }^{1} \mathrm{H}$ NMR (DMSO- $\left.d_{6}\right) ; \delta 3.76(\mathrm{~s}$, $6 \mathrm{H}), 6.47$ (s, 1H), 6.78 (s, 2H), 7.47 (d, J=3.8 Hz, 1H), 7.54 (d, J=3.8 Hz, 1H), 7.59 (d, J=3.8 Hz, 1H), 7.92 (d, J=3.8 Hz, 1H). MS (EI) m/e (rel int); $327\left(\mathrm{M}^{+}, 100\right), 296$ (5). Analysis $\left(\mathrm{C}_{17} \mathrm{H}_{13} \mathrm{NO}_{2} \mathrm{~S}_{2}\right) \mathrm{C}, \mathrm{H}, \mathrm{N}$.

\section{$\alpha$-terthienyl-2-carbonitrile (6)}

A mixture of 5'-bromo-2,2'-bithiophene-5-carbonitrile (2.7 g, $10 \mathrm{mmol}$ ), 2-(tri- $n$-butylstannyl)thiophene ( $4.13 \mathrm{~g}, 11 \mathrm{mmol}$ ), and tetrakis(triphenylphosphine)palladium $(190 \mathrm{mg})$ in dry dioxane $(20 \mathrm{~mL})$ was heated at reflux $\left(100^{\circ} \mathrm{C}-110^{\circ} \mathrm{C}\right)$ for 24 hours. The solvent was evaporated under reduced pressure, the solid was dissolved in ethyl acetate, and the solution was passed through celite to remove palladium. The solution was evaporated, and the solid was filtered and recrystallized from ethanol/pet ether to give compound 6 as a yellow solid in $67 \%$ yield, $\mathrm{mp} 127^{\circ} \mathrm{C}-128^{\circ} \mathrm{C} . \mathrm{R}_{\mathrm{f}}=0.67$, petroleum ether $\left(60^{\circ} \mathrm{C}-80^{\circ} \mathrm{C}\right)$-EtOAc (8:2). IR ( $\left.\mathrm{KBr}\right) v^{\prime} 3,087,3,065(\mathrm{CH})$, 2,215 (CN), 1,601, 1,525 (C=C) cm ${ }^{-1} .{ }^{1} \mathrm{H}$ NMR (DMSO- $\left.d_{6}\right)$; $\delta 7.12(\mathrm{~d}, \mathrm{~J}=4.8 \mathrm{~Hz}, 1 \mathrm{H}), 7.36(\mathrm{~d}, \mathrm{~J}=3.9 \mathrm{~Hz}, 1 \mathrm{H}), 7.42-7.60$ (m, 4H), 7.96 (d, J=3.9 Hz, 1H). MS (EI) m/e (rel int); 273 $\left(\mathrm{M}^{+}, 100\right)$. Analysis $\left(\mathrm{C}_{13} \mathrm{H}_{7} \mathrm{NS}_{3}\right) \mathrm{C}, \mathrm{H}, \mathrm{N}$.

General procedure for preparation of monoamidine bithiophenes and isosters $5 \mathrm{a}-5 \mathrm{c}$ and 7

5'-phenyl-2,2'-bithiophene-5-amidine hydrochloride salt (5a) The mononitrile bithiophene $4 \mathrm{a}(401 \mathrm{mg}, 1.5 \mathrm{mmol})$, suspended in freshly distilled THF $(8 \mathrm{~mL})$, was treated with LiN(TMS) 2 (1 M solution in THF, $4 \mathrm{~mL}, 4 \mathrm{mmol}$ ) and the reaction was allowed to stir overnight. The reaction mixture was then cooled to $0^{\circ} \mathrm{C}$, to which was added hydrogen chloride ethanolic solution $(12 \mathrm{~mL}, 1.25 \mathrm{M})$, whereupon a precipitate started forming. The mixture was left to run overnight, whereafter it was diluted with ether, and the resultant solid was collected by filtration. The monoamidine was purified by neutralization with $1 \mathrm{~N} \mathrm{NaOH}$, followed by filtration of the resultant solid and washing with water. Finally, the free base was stirred with hydrogen chloride ethanolic solution overnight, diluted with ether, and the solid formed was filtered and dried to give the monoamidine $5 \mathrm{a}$ hydrochloride salt as a yellow solid in $75 \%$ yield, $\mathrm{mp} 201^{\circ} \mathrm{C}-202^{\circ} \mathrm{C}$. IR $(\mathrm{KBr})$ v' 3,351, 3,200 (NH, $\left.\mathrm{NH}_{2}\right), 3,081(\mathrm{CH}), 1,657,1,567(\mathrm{C}=\mathrm{C}$, $\mathrm{C}=\mathrm{N}, \mathrm{NH}$ bending) $\mathrm{cm}^{-1} .{ }^{1} \mathrm{H}$ NMR (DMSO- $\left.d_{6}\right) ; \delta$ 7.37-7.72 (m, 8H), 8.06 (d, J=3.9 Hz, 1H), 9.21 (br s, 4H, exchangeable with $\mathrm{D}_{2} \mathrm{O}$ ). ${ }^{13} \mathrm{C}$ NMR (DMSO- $d_{6}$ ); $\delta 125.4,125.7,125.9$, 127.0, 128.3, 128.9, 129.7, 133.2, 134.0, 136.0, 144.3, 145.3, 158.8. MS (EI) m/e (rel int); $284\left(\mathrm{M}^{+}, 100\right), 268$ (46). Analysis $\left(\mathrm{C}_{15} \mathrm{H}_{12} \mathrm{~N}_{2} \mathrm{~S}_{2}-1.0 \mathrm{HCl}-1.1 \mathrm{H}_{2} \mathrm{O}\right) \mathrm{C}, \mathrm{H}, \mathrm{N}$. 


\section{5'-(4-methoxyphenyl)-2,2'-bithiophene-5-amidine} hydrochloride salt (5b)

A yellow solid in $70 \%$ yield, mp $258^{\circ} \mathrm{C}-260^{\circ} \mathrm{C}$. IR $(\mathrm{KBr})$ v' 3,351, 3,200 (NH, $\left.\mathrm{NH}_{2}\right), 3,081(\mathrm{CH}), 1,657,1,567(\mathrm{C}=\mathrm{C}$, $\mathrm{C}=\mathrm{N}, \mathrm{NH}$ bending) $\mathrm{cm}^{-1} .{ }^{1} \mathrm{H}$ NMR (DMSO- $\left.d_{6}\right) ; \delta 3.77$ (s, 3H), 7.01 (d, J=8.4 Hz, 2H), 7.45-7.66 (m, 5H), 8.04 (d, $\mathrm{J}=3.8 \mathrm{~Hz}, 1 \mathrm{H}), 9.38\left(\mathrm{br} \mathrm{s}, 2 \mathrm{H}\right.$, exchangeable with $\left.\mathrm{D}_{2} \mathrm{O}\right), 9.08$ (br s, $2 \mathrm{H}$, exchangeable with $\mathrm{D}_{2} \mathrm{O}$ ). ${ }^{13} \mathrm{C}$ NMR (DMSO- $d_{6}$ ); $\delta$ $55.8,115.1,124.5,125.0,125.9,126.5,127.4,128.4,132.8$, 136.0, 144.6, 145.6, 158.7, 160.0. MS (EI) m/e (rel int); $314\left(\mathrm{M}^{+}, 100\right), 297$ (33). Analysis $\left(\mathrm{C}_{16} \mathrm{H}_{14} \mathrm{~N}_{2} \mathrm{OS}_{2}-1.0 \mathrm{HCl}-\right.$ $\left.1.5 \mathrm{H}_{2} \mathrm{O}\right) \mathrm{C}, \mathrm{H}, \mathrm{N}$.

\section{5'-(3,5-dimethoxyphenyl)-2,2'-bithiophene-5-amidine} hydrochloride salt (5c)

A golden-yellow solid in $68 \%$ yield, $\mathrm{mp} 2515^{\circ} \mathrm{C}-252.5^{\circ} \mathrm{C}$. IR (KBr) v' 3,321, 3,200, (NH, $\left.\mathrm{NH}_{2}\right), 3,093,2,965(\mathrm{CH})$, 1,660, 1,592 $(\mathrm{C}=\mathrm{C}, \mathrm{C}=\mathrm{N}, \mathrm{NH}$ bending $) \mathrm{cm}^{-1} .{ }^{1} \mathrm{H}$ NMR (DMSO- $d_{6}$ ); $\delta 3.78(\mathrm{~s}, 6 \mathrm{H}), 6.49(\mathrm{~s}, 1 \mathrm{H}), 6.80(\mathrm{~s}, 2 \mathrm{H}), 7.54$ $(\mathrm{d}, \mathrm{J}=3.8 \mathrm{~Hz}, 1 \mathrm{H}), 7.57$ (d, J=3.8 Hz, 1H), $7.62(\mathrm{~d}, \mathrm{~J}=3.8 \mathrm{~Hz}$, 1H), 8.03 (d, J=3.8 Hz, 1H), 9.34 (br s, $2 \mathrm{H}$, exchangeable with $\mathrm{D}_{2} \mathrm{O}$ ), 9.07 (br s, $2 \mathrm{H}$, exchangeable with $\mathrm{D}_{2} \mathrm{O}$ ). ${ }^{13} \mathrm{C}$ NMR (DMSO- $d_{6}$ ); $\delta 55.9,100.7,104.2,125.5,126.4,127.0,128.2$, 134.1, 135.0, 136.0, 144.3, 145.1, 158.8, 161.5. MS (EI) m/e (rel int); $344\left(\mathrm{M}^{+}, 100\right), 327$ (76). Analysis $\left(\mathrm{C}_{17} \mathrm{H}_{16} \mathrm{~N}_{2} \mathrm{O}_{2} \mathrm{~S}_{2}^{-}\right.$ $\left.1.0 \mathrm{HCl}-1.4 \mathrm{H}_{2} \mathrm{O}\right) \mathrm{C}, \mathrm{H}, \mathrm{N}$.

\section{$\alpha$-terthienyl-2-amidine hydrochloride salt (7)}

A yellow solid in $71 \%$ yield, mp $199^{\circ} \mathrm{C}-200.5^{\circ} \mathrm{C}$. IR (KBr) v' 3,326, 3,200, 3,079 (NH, $\left.\mathrm{NH}_{2}, \mathrm{CH}\right), 1,655,1,568(\mathrm{C}=\mathrm{N}$, $\mathrm{C}=\mathrm{C}, \mathrm{NH}$ bending) $\mathrm{cm}^{-1} .{ }^{1} \mathrm{H}$ NMR (DMSO- $\left.d_{6}\right) ; \delta 7.13(\mathrm{~d}$, $\mathrm{J}=3.9 \mathrm{~Hz}, 1 \mathrm{H}), 7.38(\mathrm{~d}, \mathrm{~J}=3.9 \mathrm{~Hz}, 1 \mathrm{H}), 7.42-7.61(\mathrm{~m}, 4 \mathrm{H}), 8.09$ (d, J=3.9 Hz, 1H), 9.15 (br s, $2 \mathrm{H}$, exchangeable with $\mathrm{D}_{2} \mathrm{O}$ ), 9.42 (br s, $2 \mathrm{H}$, exchangeable with $\mathrm{D}_{2} \mathrm{O}$ ). ${ }^{13} \mathrm{C}$ NMR (DMSO- $d_{6}$ ); $\delta$ 125.5, 125.6, 125.8, 127.0, 127.1, 128.2, 129.1, 133.3, 135.8, 136.0, 138.5, 144.0, 158.8. MS (EI) $\mathrm{m} / \mathrm{e}$ (rel int); $290\left(\mathrm{M}^{+}, 100\right)$, 274 (40). Analysis $\left(\mathrm{C}_{13} \mathrm{H}_{10} \mathrm{~N}_{2} \mathrm{~S}_{3}-1.0 \mathrm{HCl}-1.25 \mathrm{H}_{2} \mathrm{O}\right) \mathrm{C}, \mathrm{H}, \mathrm{N}$.

\section{Biology}

In vitro antiproliferative screening

\section{Experimental design}

The structures of the synthesized compounds were sent to the National Cancer Institute (NCI) (Bethesda, MA, USA) for evaluation of their anticancer activity, where 15 compounds representing 12 monoamidines and three of their cyano precursors were chosen and subjected to a primary in vitro one-dose $(10 \mu \mathrm{M})$ anticancer assay using the full NCI 60 cell panel, in accordance with the current protocol of the NCI Drug Evaluation Branch. In this protocol, all compounds submitted to the screen were tested initially at a single high dose $(10 \mu \mathrm{M})$ in the full NCI panel of 60 cell lines, representing nine types of cancer (leukemia, non-small cell lung, colon, central nervous system [CNS], melanoma, ovarian, renal, prostate, and breast cancers). A 48-hour continuous drug exposure protocol was used, and a sulforhodamine B (SRB) protein assay was employed to estimate cell viability or growth. ${ }^{40-42}$ The data obtained are a mean graph of the percent growth of treated cells, presented as percentage growth inhibition (GI\%) caused by the tested compounds (Table 2). Only compounds showing high GI\% against the majority of the tested cell lines and satisfying predetermined threshold inhibition criteria set forth by the Development Therapeutic Program were selected for progression to the five-dose screen study against the panel of 60 cell lines, and the $\mathrm{GI}_{50}$ values against each cell line were determined (Table 3 ) as well as their mean $\mathrm{GI}_{50}$, TGI, and $\mathrm{LC}_{50}$ values against all tested cell lines, representing the mean graph midpoints (Table 4).

\section{Experimental procedure}

The experiment was performed under sterile conditions, where cell lines were grown in RPMI 1,640 medium (Gibco, NY, USA), supplemented with $10 \%$ fetal bovine serum (Biocell, CA, USA); $5 \times 10^{4}$ cells $/ \mathrm{mL}$ were used to test the growth inhibition activity of the tested compounds. Cell culture $(1.8 \mathrm{~mL})$ containing a cell population of $6 \times 10^{4}$ cells $/ \mathrm{mL}$ was pipetted into each well of a 96 -multiwell microtiter plate ( $10^{4}$ cells/well) 24 hours before treatment with the test compound, to allow attachment of cells to the wall of the plate. For determination of the $\mathrm{GI}_{50}$, five serial ten-fold dilutions of each compound, with concentrations ranging from $0.01 \mu \mathrm{M}$ to $100 \mu \mathrm{M}$, were prepared in saline buffer and used for the purpose. Each compound was initially solubilized in dimethylsulfoxide (DMSO); however, each final dilution contains less than $1 \%$ DMSO. Solutions of the different concentrations $(0.2 \mathrm{~mL})$ were pipetted into separate wells of a microtiter tray, in duplicates, followed by an incubation period of 48 hours

Table 2 In vitro MPGI of monocationic bichalcophenes against a panel of 60 cell lines at a single dose level (I0 $\mu M)$

\begin{tabular}{|c|c|c|c|c|c|c|c|c|c|c|c|c|c|c|c|}
\hline & \multicolumn{15}{|c|}{ Compound number } \\
\hline & Ia & Ib & Ic & Id & Ie & If & Ig & $\mathbf{l j}$ & $2 a$ & $2 b$ & $2 c$ & $5 a$ & $5 b$ & $5 c$ & 7 \\
\hline MPGI & 83.98 & 41.95 & 66.06 & -72.51 & 75.61 & -3.16 & 9.78 & 3.70 & 2.87 & 24.34 & 24.85 & $-52.8 \mathrm{I}$ & $-7 \mid .27$ & -75.15 & -44.7 I \\
\hline
\end{tabular}

Abbreviation: MPGI, mean percent growth inhibition. 
Table 3 In vitro antiproliferative activity of monocationic bithiophenes against a panel of 60 cell lines at five-dose level

\begin{tabular}{|c|c|c|c|c|c|c|c|c|c|c|}
\hline \multirow[t]{2}{*}{ Cancer type/cell line } & \multicolumn{10}{|c|}{ Compound number } \\
\hline & $\mathrm{Ia}$ & Ib & Ic & Id & le & If & $5 \mathbf{a}$ & $5 \mathbf{b}$ & $5 c$ & 7 \\
\hline \multicolumn{11}{|l|}{ Leukemia } \\
\hline CCRF-CEM & 1.88 & 3.11 & 1.65 & 0.65 & 2.33 & 2.77 & 1.29 & 0.2 & 0.28 & 1.35 \\
\hline HL-60 (TB) & $\mathrm{NT}^{\mathrm{b}}$ & 2.19 & 1.85 & 0.37 & 1.82 & 2.19 & 0.803 & 0.21 & 0.17 & 1.58 \\
\hline K-562 & 1.76 & 2.66 & 1.84 & 0.22 & 2.27 & 1.58 & 0.243 & 0.18 & 0.18 & 0.553 \\
\hline MOLT-4 & 2.14 & 3.26 & 2.06 & 0.26 & 2.34 & 2.27 & 0.905 & $0.4 I$ & 0.23 & 1.8 \\
\hline RPMI-8226 & 0.157 & 2.51 & 0.207 & 0.23 & 2.12 & 1.95 & 1.63 & 0.22 & 0.22 & 0.338 \\
\hline SR & 2.31 & 3.17 & 1.36 & 0.23 & 2.99 & 1.97 & 0.291 & 0.18 & 0.24 & 0.302 \\
\hline \multicolumn{11}{|c|}{ Non-small cell lung cancer } \\
\hline A549/ATCC & 0.034 & 4.76 & 0.017 & 0.012 & 1.89 & 3.04 & 1.75 & 0.2 & 1.03 & $<0.010$ \\
\hline HOP-62 & 1.54 & 10.4 & 1.78 & 1.29 & 2.04 & 2.96 & 1.89 & 0.21 & 1.31 & 1.74 \\
\hline HOP-92 & 2.32 & 1.38 & 0.20 & 0.17 & 1.4 & 9.68 & 0.809 & 1.03 & 0.53 & 1.06 \\
\hline $\mathrm{NCl}-\mathrm{H} 226$ & 1.19 & 14.4 & 1.57 & 1.88 & 2.07 & 2.61 & 1.56 & 2.23 & 1.77 & 0.822 \\
\hline $\mathrm{NCl}-\mathrm{H} 23$ & 1.63 & $\mathrm{II}$ & 3.43 & NT & 3.63 & NT & 1.91 & NT & NT & 1.62 \\
\hline $\mathrm{NCl}-\mathrm{H} 322 \mathrm{M}$ & 0.236 & 3.58 & 0.102 & 0.06 & 2.08 & 2.1 & 1.64 & 0.41 & 1.17 & 0.268 \\
\hline $\mathrm{NCl}-\mathrm{H} 460$ & 0.072 & 2.43 & 0.029 & 0.034 & 1.79 & 1.98 & 1.56 & 0.20 & 0.24 & $<0.010$ \\
\hline $\mathrm{NCl}-\mathrm{H} 522$ & 1.82 & 3.73 & 1.66 & 1.99 & 2.1 & 2.31 & 1.5 & 0.26 & 1.63 & 1.49 \\
\hline \multicolumn{11}{|l|}{ Colon cancer } \\
\hline COLO 205 & 0.514 & 1.78 & 0.256 & 0.19 & 1.91 & 1.8 & 0.475 & 0.48 & 0.2 & 0.208 \\
\hline HCC-2998 & 1.07 & 1.85 & 1.06 & 0.28 & 1.87 & 1.94 & 1.08 & 0.21 & 0.21 & 1.13 \\
\hline HCT-II6 & 1.92 & 3.04 & 1.54 & 0.42 & 1.83 & 1.69 & 1.14 & 1.67 & 0.17 & 1.46 \\
\hline HCT-I5 & 1.7 & 2.58 & 1.89 & 0.3 & 1.86 & 2.02 & 1.04 & 0.21 & 0.29 & 1.54 \\
\hline НT29 & 1.82 & 2.79 & 1.8 & 0.23 & 1.89 & 1.29 & 0.32 & 0.18 & 0.29 & 1.53 \\
\hline KMI2 & 1.72 & 3.16 & 1.88 & 0.49 & 1.87 & 1.92 & 0.563 & 0.18 & 0.3 & 1.47 \\
\hline SW-620 & 1.89 & 1.92 & 1.75 & 0.31 & 1.77 & 1.72 & 1.21 & 0.18 & 0.2 & 1.63 \\
\hline \multicolumn{11}{|l|}{ CNS cancer } \\
\hline SF-268 & 1.89 & 4.85 & 2.13 & 1.38 & 2.19 & 2.9 & 1.74 & 0.20 & 0.73 & 1.79 \\
\hline SF-295 & NT & NT & NT & 0.51 & NT & 1.67 & 1.59 & 0.20 & 0.19 & NT \\
\hline SF-539 & 1.65 & 8.96 & 1.45 & 1.42 & 1.68 & 1.6 & 1.67 & 0.19 & 1.38 & 1.58 \\
\hline SNB-19 & 1.71 & 9.44 & 2.38 & 1.9 & 2.43 & 2.48 & 1.72 & 0.31 & 1.59 & 1.56 \\
\hline SNB-75 & 1.47 & 10.7 & 1.95 & NT & 1.71 & 1.66 & 1.36 & 1.98 & 1.67 & 1.77 \\
\hline U25I & 1.72 & 2.92 & 1.75 & 1.07 & 1.76 & 1.72 & 1.27 & 0.18 & 0.21 & 1.71 \\
\hline \multicolumn{11}{|l|}{ Melanoma } \\
\hline LOX IMVI & 1.88 & 2.23 & 1.75 & 0.41 & 1.87 & 1.6 & 1.21 & 0.19 & 0.18 & 1.74 \\
\hline MALME-3M & 2.12 & 2.15 & 1.98 & 1.62 & 1.91 & 1.74 & 1.55 & 1.23 & NT & 1.71 \\
\hline MI4 & 1.9 & 1.9 & 1.72 & 1.37 & 1.9 & 1.88 & 1.68 & 0.18 & 0.17 & 1.55 \\
\hline MDA-MB-435 & 1.74 & 1.83 & 1.65 & 0.29 & 1.76 & 1.63 & 0.497 & 0.18 & 0.19 & 0.407 \\
\hline SK-MEL-2 & 2.38 & 2.41 & 2.42 & 2.27 & 2.19 & 2.09 & 1.92 & 2.22 & 1.91 & 2.08 \\
\hline SK-MEL-28 & 1.79 & 2.31 & 1.66 & 1.43 & I.7I & 1.81 & 1.59 & 1.9 & 1.31 & 1.69 \\
\hline SK-MEL-5 & 1.63 & 2.67 & 1.54 & 1.25 & 1.65 & 1.64 & 1.64 & 0.14 & 1.42 & 1.02 \\
\hline UACC-257 & 1.84 & 1.84 & 1.72 & 1.56 & 1.98 & 1.59 & 1.63 & 0.30 & 1.00 & 1.66 \\
\hline UACC-62 & 1.68 & 1.82 & 1.7 & NT & 1.75 & NT & 1.60 & NT & NT & 1.82 \\
\hline \multicolumn{11}{|l|}{ Ovarian cancer } \\
\hline IGROV-I & 1.84 & 4.38 & 1.73 & 1.5 & 1.92 & 2.31 & 1.61 & 0.20 & 0.55 & 1.76 \\
\hline OVCAR-3 & 0.149 & 9.77 & 0.135 & 1.18 & 2.25 & 3.06 & 1.84 & 0.19 & 1.43 & $N T^{b}$ \\
\hline OVCAR-4 & 1.71 & 6.42 & 1.25 & 1.2 & 2.45 & 2.88 & 1.72 & 0.20 & 0.77 & 1.03 \\
\hline OVCAR-5 & 1.2 & 4.98 & 1.12 & 1.19 & 2.02 & 2.7 & 1.56 & 0.22 & 1.49 & 1.21 \\
\hline OVCAR-8 & 1.98 & 8.22 & 1.68 & 1.73 & 2.01 & 2.31 & 2.16 & 0.19 & 0.21 & 1.77 \\
\hline $\mathrm{NCI} / \mathrm{ADR}-\mathrm{RES}$ & 1.78 & 10.1 & 2.83 & 1.77 & 2.88 & 2.66 & 1.96 & 0.31 & 0.89 & 1.79 \\
\hline SK-OV-3 & 13.5 & 9.21 & 1.51 & 1.51 & 2.4 & 3.2 & 1.83 & 2.14 & 1.82 & 1.4 \\
\hline \multicolumn{11}{|l|}{ Renal cancer } \\
\hline $786-0$ & 1.76 & 3.93 & 1.63 & 1.19 & 1.89 & 1.74 & 1.94 & 0.19 & 1.39 & 1.79 \\
\hline A498 & 0.462 & 6.58 & 0.274 & 0.22 & 1.8 & 1.36 & 1.03 & 1.17 & 1.39 & 0.279 \\
\hline $\mathrm{ACHN}$ & 1.70 & 4.24 & 1.68 & 1.41 & 1.86 & 1.84 & NT & 0.19 & 0.34 & 1.66 \\
\hline CAKI-I & 1.70 & 3.94 & 1.63 & 1.59 & 2.14 & 1.78 & 1.57 & 0.31 & 1.07 & 1.57 \\
\hline RXF 393 & 1.34 & 4.68 & 1.82 & 1.13 & 1.69 & 1.62 & 1.16 & 1.24 & 0.84 & 0.29 \\
\hline SNI2C & 1.52 & 5.97 & 1.52 & 1.13 & 1.97 & 2.01 & 1.70 & 0.20 & 0.28 & 1.58 \\
\hline
\end{tabular}


Table 3 (Continued)

\begin{tabular}{|c|c|c|c|c|c|c|c|c|c|c|}
\hline \multirow[t]{2}{*}{ Cancer type/cell line } & \multicolumn{10}{|c|}{ Compound number } \\
\hline & Ia & Ib & Ic & Id & le & If & $5 \mathbf{a}$ & $5 \mathbf{b}$ & $5 c$ & 7 \\
\hline TK-10 & 1.40 & 4.33 & 1.03 & $\mid .5 \mathrm{I}$ & 1.95 & 1.69 & NT & 0.18 & 0.65 & 1.48 \\
\hline UO-3I & 0.724 & 3.17 & 0.297 & 1.09 & 1.90 & 1.43 & 1.62 & 0.16 & 1.39 & 0.318 \\
\hline \multicolumn{11}{|l|}{ Prostate cancer } \\
\hline PC-3 & 1.64 & 4.05 & 1.56 & NT & 2.13 & NT & 1.45 & NT & NT & 1.53 \\
\hline DU- 145 & 1.69 & 6.25 & 1.72 & 1.44 & 1.9 & 3.27 & 1.73 & 0.19 & 0.47 & 1.52 \\
\hline \multicolumn{11}{|l|}{ Breast cancer } \\
\hline MCF-7 & 1.41 & 2.08 & 1.27 & 0.53 & 1.69 & 1.83 & 1.03 & 0.19 & 0.28 & 0.535 \\
\hline MDA-MB-23I/ATCC & 1.78 & 2.75 & 1.62 & 0.56 & 1.82 & 1.60 & 1.45 & 0.19 & 0.25 & 1.50 \\
\hline HS-578T & 2.99 & 4.82 & 1.55 & $\mathrm{I} .37$ & 2.14 & 1.53 & NT & 0.29 & 0.33 & 1.85 \\
\hline BT-549 & 1.99 & 5.9 & 2.78 & 1.52 & 2.05 & 2.19 & 1.86 & 1.66 & 1.52 & 1.80 \\
\hline $\mathrm{T}-47 \mathrm{D}$ & 1.87 & 2.92 & 2.11 & 0.48 & 2.17 & 2.05 & 1.66 & 0.20 & 0.38 & 1.42 \\
\hline MDA-MB-468 & 0.182 & 1.39 & 0.073 & 0.079 & 1.72 & 1.57 & 1.22 & 0.20 & 0.23 & 0.217 \\
\hline
\end{tabular}

Notes: Data represent the compounds' $\mathrm{GI}_{50}$ in $\mu \mathrm{M}$ against the tested cell lines.

Abbreviations: $\mathrm{Gl}_{50}$, drug concentration that causes $50 \%$ inhibition of cell growth; NT, not tested; CNS, central nervous system.

at $37^{\circ} \mathrm{C}$ in an atmosphere of $5 \% \mathrm{CO}_{2}$. Thereafter, cells were fixed, washed, and stained for 30 minutes with $0.4 \%(\mathrm{w} / \mathrm{v})$ SRB dissolved in 1\% acetic acid. Excess, unbound dye was removed by four washes with $1 \%$ acetic acid, and attached stain was recovered with Tris-EDTA buffer. Color intensity was measured in an ELISA reader at a wavelength of $570 \mathrm{~nm}$. Controls, containing only phosphate buffer (PB), saline, and DMSO, at identical dilutions, were also prepared and tested in the same manner.

\section{Nuclease-like activity assay}

Genomic DNA extracted from E. coli K91, according to reported methodology, ${ }^{43}$ was used for the nuclease-like activity assay of the tested bichalcophenes. DNA purity and concentration were examined at 260/280 nm, spectrophotometrically. The bichalcophene compounds were dissolved in DMSO $(0.5 \mathrm{mg} / \mathrm{mL})$ and $2 \mu \mathrm{g}, 4 \mu \mathrm{g}$, and $6 \mu \mathrm{g}$ were added individually to $2 \mu \mathrm{g}$ of the $E$. coli DNA. DNA alone and DNA with DMSO were used as a control. The reactions were carried out at $37^{\circ} \mathrm{C}$ for 30 minutes. A solution of $10 \%$ $\mathrm{w} / \mathrm{v}$ ficol 400, 0.06\% w/v bromophenol blue, and 0.5\% w/v SDS was added to the reaction mixtures prior to running the gel. The DNA was analyzed by using horizontal agarose gel electrophoresis. The electrophoresis was performed using $1.0 \%$ agarose gel at a constant voltage of $80 \mathrm{~V}$ for 60 minutes in TEA buffer (40 mM Tris- $\mathrm{HCl}$ pH 7.9, $5 \mathrm{mM}$ sodium acetate, $1 \mathrm{mM}$ EDTA). The agarose gels were stained with ethidium bromide $(0.5 \mu \mathrm{g} / \mathrm{mL})$, visualized under a UV transilluminator, and photographed using a digital camera.

\section{ABTS radical cation decolorization assay}

ABTS [2,2'-azino-bis(3-ethylbenzthiazoline-6-sulfonic acid) diammonium salt] forms a relatively stable free radical, which decolorizes in its non-radical form. The analysis of $\mathrm{ABTS}^{+}$scavenging activity was measured spectrophotometrically, according to the method of Re et al. ${ }^{44}$ A mixture of ABTS (1 mL, $0.1 \mathrm{~g} / 100 \mathrm{~mL})$ and $\mathrm{MnO}_{2}(1.5 \mathrm{~mL}, 25 \mathrm{mg} / \mathrm{mL})$, prepared in $\mathrm{PB}$ (pH 7.4, $100 \mathrm{mM}$ ) was vortexed, centrifuged, and decanted. Prior to assay, the resulting green-blue solution was diluted in PB to give an absorbance $\left(\mathrm{A}_{\text {control }}\right.$ of ABTS radical solution) at $734 \mathrm{~nm}$ of 0.600 in a $1 \mathrm{~cm}$ cuvette, and equilibrated to $30^{\circ} \mathrm{C}$ (the temperature at which all the assays were done). Antioxidant activities of the tested bichalcophenes were estimated from the radical cations of ABTS.

Table 4 Median $\mathrm{GI}_{50}, \mathrm{TGI}$, and $\mathrm{LC}_{50}$ for the most active monocationic bithiophenes against a panel of 60 cell lines at five dose level

\begin{tabular}{|c|c|c|c|c|c|c|c|c|c|c|}
\hline \multirow[t]{2}{*}{ MG-MID } & \multicolumn{10}{|c|}{ Compound number } \\
\hline & Ia & Ib & Ic & Id & Ie & If & $5 \mathbf{a}$ & $5 b$ & $5 c$ & 7 \\
\hline $\mathrm{Gl}_{50}$ & 1.28 & 3.71 & 1.07 & 0.63 & 1.99 & 1.94 & 1.28 & 0.30 & 0.52 & 0.95 \\
\hline TGI $(\mu \mathrm{M})$ & 3.38 & 11.48 & 3.23 & 1.99 & 4.26 & 5.28 & 2.88 & 0.71 & 1.58 & 2.51 \\
\hline $\mathrm{LC}_{50}(\mu \mathrm{M})$ & 17.78 & 36.3 & 10.71 & 48.9 & 13.8 & 17.37 & 10 & 2.39 & 19.05 & 7.58 \\
\hline
\end{tabular}

Abbreviations: MG-MID, mean graph midpoint, representing mean sensitivity of all examined cell lines to the test compound; $\mathrm{Gl}_{50}$, compound concentration causing $50 \%$ growth inhibition of tested cells; TGI, compound concentration causing $100 \%$ growth inhibition of tested cells; $\mathrm{LC}_{50}$, compound concentration causing $50 \%$ lethality of tested cells. 
The absorbance $\left(\mathrm{A}_{\text {test }}\right)$ was measured upon the addition of 2 $\mu \mathrm{g}$ of the bichalcophenes in DMSO/PB $(1: 1 \mathrm{v} / \mathrm{v})$ to the ABTS mixture. Ascorbic acid was used as a standard antioxidant (positive control). Blank samples were run by solvent without ABTS. The decrease in absorbance is expressed as \% inhibition, which is calculated from the following formula:

$$
\% \text { inhibition }=\left(\left[\mathrm{A}_{\text {control }}-\mathrm{A}_{\text {test }}\right] / \mathrm{A}_{\text {control }}\right) \times 100
$$

where $\mathrm{A}_{\text {control }}$ is the absorbance of the control reaction (containing all reagents except the test compound) and $\mathrm{A}_{\text {test }}$ is the absorbance of the test compound. All data about total antioxidant activity are the averages of triplicate analyses.

\section{Nitric oxide scavenging assay}

A nitric oxide scavenging activity assay was carried out according to the reported methodology, ${ }^{45}$ where sodium nitroprusside generates NO radicals, which interact with oxygen to produce nitrite ions. These can be estimated using the Greiss reagent [ $1 \%$ sulfanilamide, $2 \% \mathrm{H}_{3} \mathrm{PO}_{4}$, and $0.1 \%$ N-(1-naphthyl)ethylenediamine dihydrochloride]. Scavengers of NO compete with oxygen, leading to less production of nitrite ions. For the experiment, sodium nitroprusside $(10 \mathrm{mM})$ in PB saline was mixed with bichalcophenes $(2 \mu \mathrm{g})$ and standard. The reaction mixtures were incubated at room temperature for 150 minutes at $25^{\circ} \mathrm{C}$ and, after that, $0.5 \mathrm{~mL}$ of Griess reagent was added. The absorbance of the pink color formed during diazotization of nitrite with sulfanilamide and subsequent coupling with naphthylethylenediamine was read at $546 \mathrm{~nm}$ and referred to the absorbance of standard solutions of sodium nitrite, treated in the same way with Griess reagent. ${ }^{46}$ Nitric oxide scavenging activity was calculated by the following equation:

$\%$ nitric oxide scavenging activity $=\left[\left(\mathrm{A}_{\text {control }}-\mathrm{A}_{\text {test }}\right) / \mathrm{A}_{\text {blank }}\right]$ $\times 100$

where $\mathrm{A}_{\text {control }}$ is the absorbance of the control reaction (containing all reagents except the test compound) and $A_{\text {test }}$ is the absorbance of the test compound. All data about total antioxidant activity are the average of triplicate analyses.

\section{Total antioxidant activity determination}

in linoleic acid emulsion

The antioxidant activity of the bichalcophene compounds was determined according to the reported ferric thiocyanate methodology. ${ }^{47}$ The bichalcophenes $(2 \mu \mathrm{g} / \mathrm{mL}$ in DMSO/PB $\mathrm{v}: \mathrm{v} 1: 1)$ was prepared and added to $2.5 \mathrm{~mL}$ of linoleic acid emulsion in PB. The linoleic acid emulsion was prepared by homogenizing $15.5 \mu \mathrm{L}$ of linoleic acid, $17.5 \mathrm{mg}$ of Tween-20 as emulsifier, and $5 \mathrm{~mL}$ PB. The control was composed of $2.5 \mathrm{~mL}$ of linoleic acid emulsion and $2.5 \mathrm{~mL}$ PB. The reaction mixture $(5 \mathrm{~mL})$ was incubated at $37^{\circ} \mathrm{C}$ for 30 minutes. The peroxide levels were determined by recording the absorbance at $500 \mathrm{~nm}$ after reaction with $\mathrm{FeCl}_{2}$ and $\mathrm{SCN}$, at intervals during incubation. The peroxides formed during linoleic acid peroxidation oxidize $\mathrm{Fe}^{2+}$ to $\mathrm{Fe}^{3+}$, which forms a complex with $\mathrm{SCN}$ that has a maximum absorbance at $500 \mathrm{~nm}$. Therefore, high absorbance indicates high linoleic acid oxidation. The solutions without added bichalcophenes or standards were used as blank samples. The percent inhibition of lipid peroxidation in linoleic acid emulsion was calculated by the following equation:

$\%$ inhibition of lipid peroxidation $=100-\left(\mathrm{A}_{\text {test }} / \mathrm{A}_{\text {control }} \times 100\right)$

where $\mathrm{A}_{\text {control }}$ is the absorbance of the control reaction, which contains only linoleic acid emulsion and PB. $A_{\text {test }}$ is the absorbance of the sample in the presence of bichalcophene compounds. All data about total antioxidant activity are the average of triplicate analyses.

\section{Results and discussion Chemistry}

Monocationic bichalcophenes (1a-1j) and mononitrile bichalcophenes (2a-2c) (Figure 2) were prepared according to our previously-reported methodology. ${ }^{11,30}$ The synthesis of novel monocationic bithiophene derivatives $(5 \mathrm{a}-5 \mathrm{c})$ begins with the Suzuki coupling reaction of $5^{\prime}$-bromo-2,2'-bithiophene5-carbonitrile with the corresponding phenylboronic acid derivatives to furnish the mononitrile bithiophene derivatives $(4 a-4 c)$ (Figure 3$)$. The mononitriles were converted to the corresponding monoamidines by the action of lithium trimethylsilylamide [LiN(TMS) $)_{2}$ in tetrahydrofuran (THF). Whereas, the $\alpha$-terthienyl-2-amidine (7) was synthesized in two steps, starting with Stille coupling reaction of 5'-bromo2,2'-bithiophene-5-carbonitrile with 2-(tri- $n$-butylstannyl) thiophene to yield $\alpha$-terthienyl-2-carbonitrile, followed by direct treatment with LiN(TMS), The newly synthesized compounds ( $4 a-4 c, 5 a-5 c, 6$, and 7) were assigned based on their spectral and elemental analyses.

\section{Biology}

\section{In vitro antiproliferative screening}

A series of 15 monocationic bithiophenes and isosteres was subjected to an in vitro antiproliferative screening against 
<smiles>[R]c1[Z](-c2[X]c(-c3[Y]ccc3)cc2)ccc1C(=N)N</smiles>

Code: $R \quad Z \quad X \quad Y$

1a $\mathrm{H} \quad \mathrm{CH} \quad \mathrm{S} \quad \mathrm{S}$

1b $\mathrm{H} \quad \mathrm{CH} \quad \mathrm{O} \quad \mathrm{O}$

1c $\mathrm{H} \quad \mathrm{N} S \mathrm{~S}$

1d $\mathrm{F} \quad \mathrm{CH} \quad \mathrm{S} S$

1e $\mathrm{H} \quad \mathrm{CH} \quad \mathrm{O} \quad \mathrm{S}$

1f $\mathrm{F} \quad \mathrm{CH} \quad \mathrm{O} \quad \mathrm{O}$

$1 \mathrm{H} \quad \mathrm{N} O \mathrm{~S}$

1j $\quad \mathrm{H} \quad \mathrm{N} \quad \mathrm{O} \quad \mathrm{O}$<smiles>[R]c1[Z]c(-c2[X]c(-c3ccc[Y]3[H])cc2)ccc1C#N</smiles>

$\begin{array}{rllll}\text { Code: } & \mathbf{R} & \mathbf{Z} & \mathbf{X} & \mathbf{Y} \\ \mathbf{2 a} & \mathrm{H} & \mathrm{N} & \mathrm{S} & \mathrm{S} \\ \mathbf{2 b} & \mathrm{F} & \mathrm{CH} & \mathrm{S} & \mathrm{S} \\ \mathbf{2 c} & \mathrm{F} & \mathrm{CH} & \mathrm{O} & \mathrm{S}\end{array}$

2b $F \quad \mathrm{CH} \quad \mathrm{S} S$

Figure 2 Our previously reported bichalcophenes subjected to in vitro antiproliferative screening.

a panel of 60 cell lines, representing nine cancer types (leukemia, non-small cell lung, colon, CNS, melanoma, ovarian, renal, prostate, and breast cancers) at the NCI. The standard practice is testing the chosen compounds at an initial high dose $(10 \mu \mathrm{M})$. Thereafter, the compounds showing satisfactorily high percent growth inhibition (GI\%) of the tested cell lines (ten, in this research work) are subjected to a five-dose screen against the panel of 60 cell lines, and their half maximal inhibitory concentration $\left(\mathrm{IC}_{50}\right)$ values are determined.

Table 2 shows the mean percent growth inhibition (MPGI) results for the initial, single-dose screen against the panel of

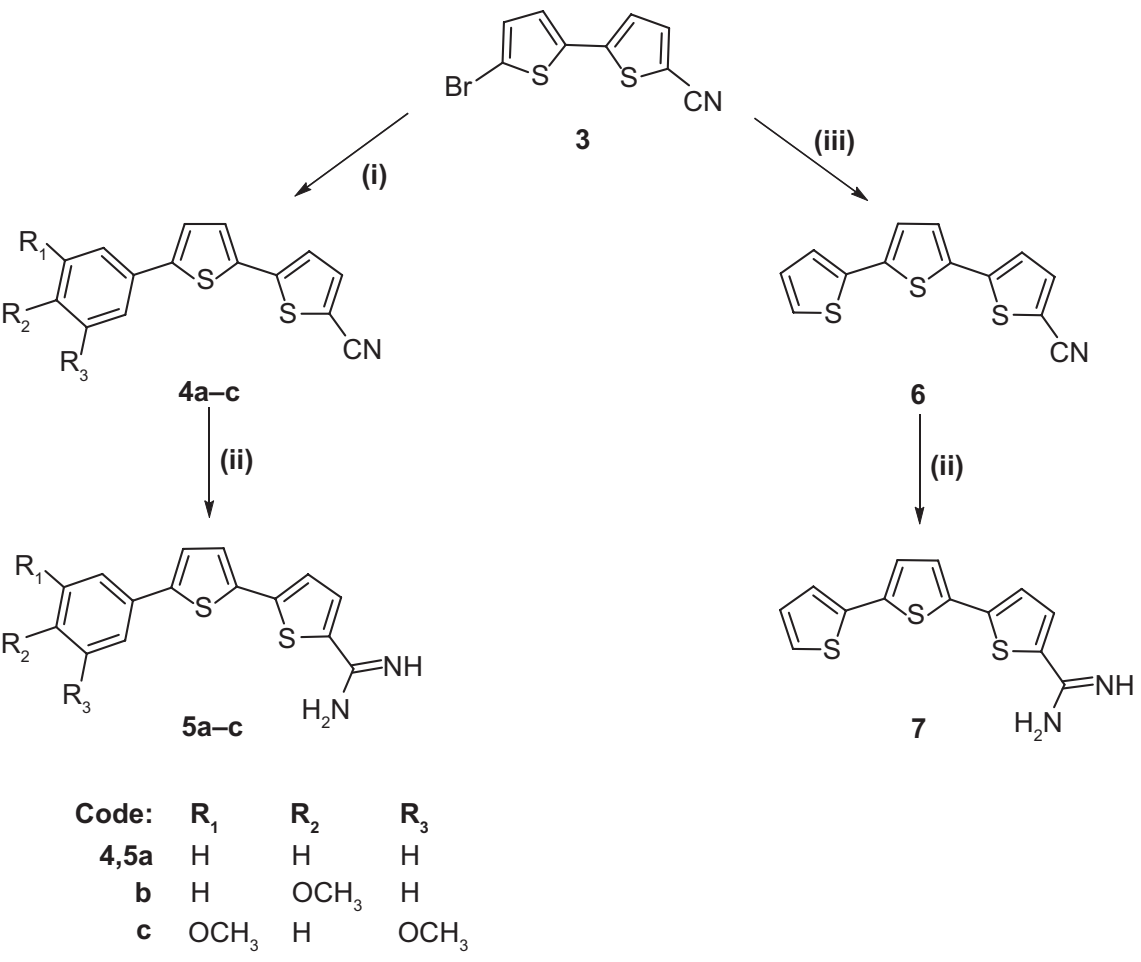

Figure 3 Newly synthesized bithiophene derivatives.

Notes: Reagents and conditions: (i) phenylboronic acid derivatives, $\mathrm{Pd}\left(\mathrm{PPh}_{3}\right)_{4}, \mathrm{NaHCO}_{3}$, toluene, $80^{\circ} \mathrm{C}$; (ii) $\mathrm{LiN}(\mathrm{TMS})_{2}$, THF, room temperature, overnight; $\mathrm{HCl}$ (gas), dry ethanol, room temperature, overnight; (iii) 2-(tri-n-butylstannyl)thiophene, $\mathrm{Pd}\left(\mathrm{PPh}_{3}\right)_{4}, 1,4$-dioxane, $100^{\circ} \mathrm{C}-110^{\circ} \mathrm{C}$. 
60 cancer cell lines, exhibited by the 12 monoamidines plus three of the mononitrile intermediates that were selected by NCI for a primary evaluation of activity of these derivatives. As a beginning, it was found that the mononitrile precursors exemplified by $2 \mathrm{a}-2 \mathrm{c}$ displayed MPGIs of $2.87,24.34$, and 24.85 , respectively. These mononitrile derivatives were far less active than their monoamidine derivatives (1c-1e), which elicited MPGI values of 66.06, 72.51, and 75.61, respectively. For that reason, the mononitrile derivatives were not progressed to the five-dose screen. These primary results clearly indicate that the presence of the amidine group plays a fundamental role in the antiproliferative activity of this class of compounds.

A close look at the structure-activity relationship findings among the 12 monoamidine derivatives gave insight about the structural features associated with enhanced antiproliferative activity of this class of compounds. First, it was shown that the bioisosteric replacement of a thiophene ring by a furan leads to a reduction in antiproliferative activity, the effect being more profound upon substitution of the two thiophene rings by furans. This is evidenced by the witnessed MPGI results of the bithiophene 1a (83.98), the thienofuran 1e (75.61), and the bifuran analogue1b (41.95). A similar pattern was observed for the analogues of $1 \mathrm{a}, 1 \mathrm{e}$, and $1 \mathrm{~b}$, where the corresponding aza derivatives displayed MPGI of 66.06 (for the bithiophene 1c), 9.78 (for the thienofuran $1 \mathrm{~g}$ ), and 3.70 (for the bifuran $1 \mathrm{j}$ ). Also, the fluorophenylbithiophene $1 \mathrm{~d}$ and bifuran $1 \mathrm{f}$ counterparts followed the same behavior (MPGI: -72.51 and -3.16 , respectively).

Studying the effect of substitution on, or isosteric replacement of, the phenyl ring of the phenylbichalcophenes, it was found that the aza analogues having a pyridyl ring in the place of the phenyl, suffered a decrease in MPGI, as evidenced by the isosteric pairs $1 \mathrm{a} / 1 \mathrm{c}, 1 \mathrm{e} / 1 \mathrm{~g}$, and $1 \mathrm{~b} / 1 \mathrm{j}$. On the other hand, fluorine substitution on the phenyl ring leads to a profound enhancement of antiproliferative activity, as shown by the isosteric pairs $1 \mathrm{a} / 1 \mathrm{~b}$ and $1 \mathrm{~d} / 1 \mathrm{f}$, even turning these derivatives from only being cytostatic to being cytotoxic (having negative MPGI values). This may be explained in terms of the fluorine substitution leading to the seemingly orthogonal effects of increasing local polarity and molecular hydrophobicity, consequently changing their pharmacokinetic properties. ${ }^{31,32}$

Attempting to understand the effect of positional isomerism on the antiproliferative effect of these derivatives, a number of compounds ( $5 \mathrm{a}-5 \mathrm{c}$ and 7 ), where the amidine moiety was moved from the phenyl to the thiophene side, were prepared. Biological screening data of 5a (MPGI $=-52.81)$, the positional isomer of $1 \mathrm{a}(\mathrm{MPGI}=83.98)$, demonstrated not only a potentiation of the antiproliferative efficacy but also a great enhancement of cytotoxic activity of this analogue. Indeed, this was the case for the 4-methoxyphenyl derivative 5b (MPGI =-71.27) and the 3,5-dimethoxyphenyl analogue 5c (MPGI =-75.15), still having the amidine functionality on the thiophene ring and showing even more enhancement of their cytotoxic abilities compared to 5a. Finally, bioisosteric replacement of the phenyl ring in 5a by a third thiophene ring (in 7) led to a slight decrease in MPGI but still maintained the compound's cytotoxic power.

On the other hand, Table 3 displays the individual $\mathrm{GI}_{50}$ values (drug concentration that causes $50 \%$ inhibition of cell growth) of the ten monoamidine derivatives that were promoted for a 5-dose screen, due to their high antiproliferative profiles demonstrated in the primary single-dose screening assay against a panel of 60 cancer cell lines. Among the nine types of cancer involved in this assay, nonsmall cell lung cancer cell lines were the most responsive to the antiproliferative effect of the tested monoamidines, especially the A549/ATCC, NCI-H322M, and NCI-H460 cell lines. Particularly, derivatives 1a, 1c, 1d, and 7 showed profound growth-deterring power against these three cell lines, with $\mathrm{GI}_{50}$ values in the nanomolar scale, in a range of less than $10 \mathrm{nM}$ to $102 \mathrm{nM}$. In addition, compounds $1 \mathrm{c}$ and $1 \mathrm{~d}$ showed good activity against the MDA-MB-468 breast cancer cell line, with $\mathrm{GI}_{50}$, values of $73 \mathrm{nM}$ and 79 $\mathrm{nM}$, respectively.

Finally, Table 4 depicts the median $\mathrm{GI}_{50}$, TGI (concentration causing $100 \%$ growth inhibition of tested cells), and $\mathrm{LC}_{50}$ (concentration causing $50 \%$ lethality of tested cells) of the compounds tested in the five-dose screen. The most active compounds, in compliance with the primary one-dose cell growth percent inhibition assay, were found to be $5 \mathrm{~b}, 5 \mathrm{c}, 1 \mathrm{~d}$, and 7 , displaying sub-micromolar $\mathrm{GI}_{50}$ values of $0.30 \mu \mathrm{M}, 0.52 \mu \mathrm{M}, 0.63 \mu \mathrm{M}$, and $0.95 \mu \mathrm{M}$, respectively. All the other compounds exhibited $\mathrm{GI}_{50}$ values below $2 \mu \mathrm{M}$, except for $1 \mathrm{~b}\left(\mathrm{GI}_{50}=3.71 \mu \mathrm{M}\right)$, which was the least active in the primary single-dose screen assay. The most potent amidine in this study was $5 \mathrm{~b}$, showing a submicromolar TGI of $0.71 \mu \mathrm{M}$ and $\mathrm{LC}_{50}$ of $2.39 \mu \mathrm{M}$. The terthienyl derivative 7 comes second, with a TGI of $2.51 \mu \mathrm{M}$ and $\mathrm{LC}_{50}$ of $7.58 \mu \mathrm{M}$. In spite of the fact that $1 \mathrm{~d}$ showed high potency with regard to its growth inhibitory abilities, reflected in its $\mathrm{GI}_{50}$ and TGI values $(0.63 \mu \mathrm{M}$ and $1.99 \mu \mathrm{M}$, respectively), yet it was the least cytotoxic in this series, with an $\mathrm{LC}_{50}$ of $48.9 \mu \mathrm{M}$. Finally, derivative $1 \mathrm{~b}$, which had the lowest MPGI among the ten monocationic 
compounds selected for the five-dose screening assay, was still the least potent with regards to the two measured parameters, $\mathrm{GI}_{50}$ and TGI.

\section{DNA affinity and DNA cleavage ability}

The nuclease-like and cleavage efficiency of the bichalcophene compounds, compared to that of controls, is due to their efficient DNA binding and degradation ability. The tested bichalcophenes were allowed to interact with genomic DNA isolated from Escherichia coli for cleavage study. In the present investigation, the bichalcophenes have shown increase in nuclease-like activities in a concentrationdependent manner, which illustrates their binding ability with genomic DNA (Figure 4). The nuclease-like activity of the bichalcophenes was investigated under aerobic conditions at $37^{\circ} \mathrm{C}$ and in the absence of any external additives. The experimental observations demonstrated that the bichalcophene compounds have promising ability toward the cleavage of genomic DNA. The obtained results showed that the examined monocationic bichalcophenes, at $4 \mu \mathrm{g}$ and $6 \mu \mathrm{g}$, are strongly capable of degrading the DNA (Figure 4B and C), while at $2 \mu \mathrm{g}$, the monocationic bichalcophenes exhibited weak degradation effect on the DNA (Figure 4A). After 30 minutes of incubation, genomic DNA was strongly degraded at $4 \mu \mathrm{g}$ of monocationic bithiophene derivatives $1 \mathrm{a}, 1 \mathrm{~d}, 1 \mathrm{e}, 5 \mathrm{~b}, 5 \mathrm{c}$, and 7 , while at $6 \mu \mathrm{g}$ of these compounds, the genomic DNA was completely degraded (Figure 4B and C). On the other hand, the observed DNA smear with the monocationic bifuran derivatives $1 \mathrm{~b}, 1 \mathrm{f}$ and, $1 \mathrm{j}$, at $6 \mu \mathrm{g}$, may be due to their cytostatic binding aptitude. In contrast, the mononitrile bichalcophene compounds $2 \mathrm{a}, 2 \mathrm{~b}$, and $2 \mathrm{c}$, at $2 \mu \mathrm{g}, 4 \mu \mathrm{g}$, and $6 \mu \mathrm{g}$, did not exhibit any nuclease-like activity toward the genomic DNA, as represented (Figure 4A-C). The weak DNA cleavage ability of the mononitriles $2 \mathrm{a}-2 \mathrm{c}$, compared against the corresponding monoamidines, may be attributed to the differences in pharmacokinetic properties of the nitrile group and the amidine group. These results indicate that the DNA cleavage activity of bichalcophene compounds depends on the structure and the concentration of the examined bichalcophenes. The monocationic bichalcophenes doses utilized in DNA cleavage were high, compared against cellular doses, because DNA cleavage is a qualitative study, while the cellular assay is quantitative. The data on DNA cleavage by bichalcophenes were in agreement with those previously reported. ${ }^{11}$ It was noted that replacing one or more of the furan rings with a thiophene ring results in an increase in the DNA cleavage affinity, as witnessed in the pattern displayed by the bifuran $1 \mathrm{~b}$, the thienofuran $1 \mathrm{e}$, and the bithiophene 1a (Figure 4A-C). This result is consistent with the increased affinity of other thiophene-based amidines, in comparison to furan counterparts, and this may be attributed to the differences in van der Waals radii between $\mathrm{S}$ and $\mathrm{O}$ atoms. ${ }^{10,33}$ The weak DNA cleavage ability of the aza derivatives $1 \mathrm{~g}$ and $1 \mathrm{c}$, compared against the phenyl counterparts 1e and 1a (Figure 4B), is consistent with the decreased affinity of other aza analogue-based amidines, in comparison to phenyl counterparts. ${ }^{34}$ The reduction in the cleavage affinity of the aza analogues is consistent with their increased hydrophilic properties, as a result of the presence of nitrogen atoms. This result suggests the importance of the hydrophobic component for minor groove DNA binding affinity. ${ }^{16,34}$ The monocationic bichalcophene compounds have attracted special attention as endonuclease mimics, due to their interesting structural features and the importance of bichalcophene curvature structure for its interaction with the human telomeric quadruplex sequence, with a recently reported, unique CD exciton-type splitting pattern. ${ }^{35}$ A previously reported finding suggested that dicationic bifuran molecule DB832 can form a stacked molecular complex ${ }^{35}$ and can bind with the quadruplex. ${ }^{17-19}$ Two mechanisms have been hypothesized from the DNA study. The first hypothesis is that monocationic bichalcophenes may bind to the DNA, forming a complex, ${ }^{35}$ thus preventing DNA from further interacting with ethidium bromide; therefore, the monocationic bichalcophene-DNA adduct was not visualized in the agarose gel. The second postulated mechanism of DNA cleavage is through a hydrolytic pathway. ${ }^{11,36,37}$ We excluded the oxidative DNA damage mechanism, due to the good antioxidant properties of monocationic bichalcophenes. The present study demonstrates that the monocationic bichalcophenes $1 \mathrm{a}, 1 \mathrm{~d}, 1 \mathrm{f}$, $1 \mathrm{e}, 5 \mathrm{~b}, 5 \mathrm{c}$, and 7 have a significant nuclease-like activity toward the cleavage of genomic DNA, in the absence of any external additives, at low concentrations. The DNA cleavage activity without any additive is an appreciated feature of the monocationic bichalcophenes, as promising chemotherapeutic agents in anticancer treatments.

\section{Antioxidant activity}

Since the DNA binding experiments conducted so far have revealed that the monocationic bichalcophenes exhibit good DNA binding affinity, it was considered worthwhile to study the antioxidant activity of this promising type of compound. The ABTS assay is widely used for assessing the ability of $\mathrm{ABTS}^{+}$radical scavenging activity. Because 
A

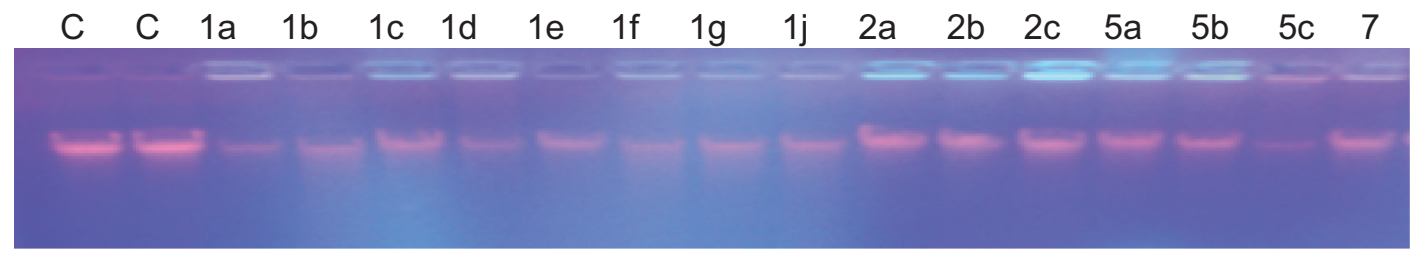

B

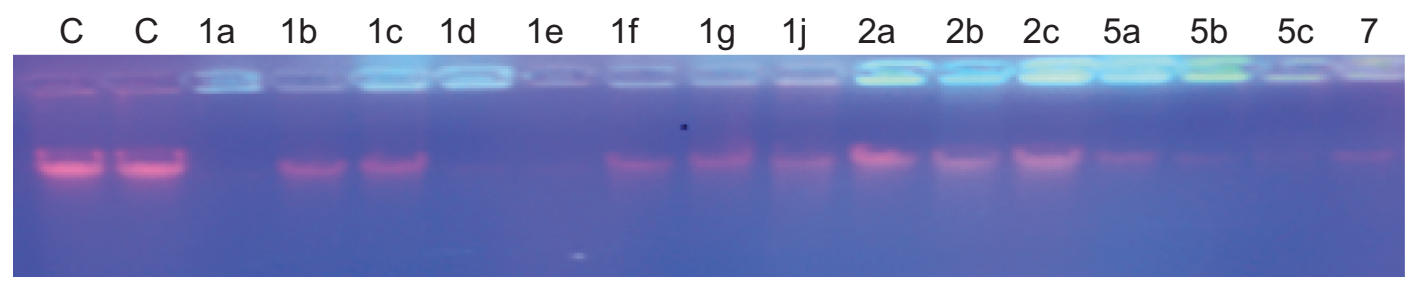

C

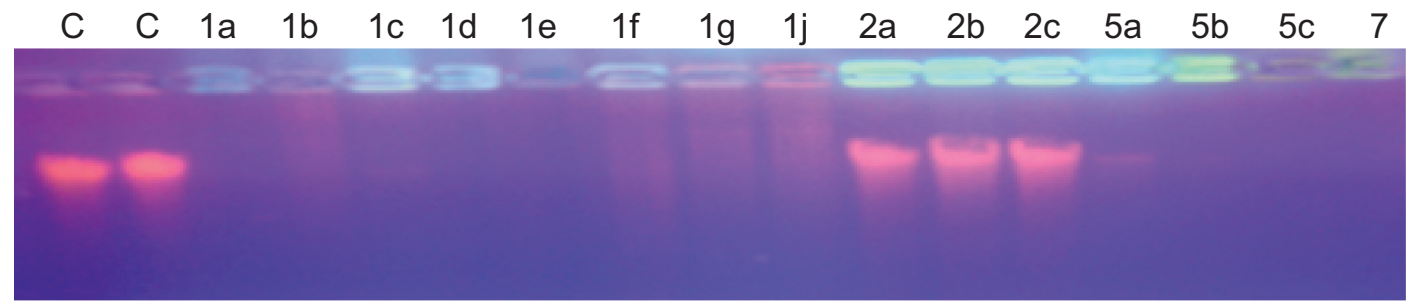

Figure 4 The degradation effect of the bichalcophene series on the genomic DNA isolated from Escherichia coli strain K9I.

Notes: (A) $2 \mu \mathrm{g}$; (B) $4 \mu \mathrm{g}$; (C) $6 \mu \mathrm{g}$ bichalcophene. Lane I: E. coli DNA; Lane 2: E. coli DNA + DMSO; Lanes 3-17: E. coli DNA + tested bichalcophenes. Abbreviation: DMSO, dimethyl sulfoxide.

of the presence of a relatively stable free radical cation, the ABTS assay shows a strong absorption band at $734 \mathrm{~nm}$ in the visible spectrum. The antioxidant activities of 15 bichalcophenes were evaluated, and the highest bichalcophenes scavenging effects with ABTS radical were in the order $1 \mathrm{a}>5 \mathrm{a}>5 \mathrm{c}>1 \mathrm{~d}>1 \mathrm{e}>1 \mathrm{~b}$, as represented in Table 5 , whereas, compounds $1 \mathrm{c}, 1 \mathrm{f}, 1 \mathrm{~g}$, and 7 displayed good activity. The monocationic bithiophenes 1a, 5a, 5c, and 1d exhibited better activity, compared against the other bichalcophenes. On the other hand, the mononitrile compounds $2 \mathrm{a}, 2 \mathrm{~b}$, and $2 \mathrm{c}$ showed weak scavenging activities with ABTS (Table 5), and this result is consistent with their weak DNA cleavage and antiproliferative activities. Thus, it would appear that introducing an amidine group, or replacing a furan ring with a thiophene unit, enhances the antioxidant properties of bichalcophene moieties.

The bichalcophene compounds were also tested for their antioxidant property by the nitric oxide scavenging activity assay technique (Figure 5). The monocationic bichalcophenes 1a, 1b, 1c, 1d, 1e, 5a, 5b, and 5c showed good radical scavenging activity. The other monocationic bichalcophenes $1 \mathrm{f}$, $1 \mathrm{~g}, 1 \mathrm{j}$, and 7 showed moderate antioxidant activity, whereas, the mononitrile bichalcophenes 2a, 2b, and 2c displayed weak nitric oxide scavenging, compared against the control. The ability of the monocationic bichalcophenes to counteract the effect of NO formation represents an opportunity of considerable interest in preventing the severe effects of excessive NO generation in the biological system. This study demonstrated that monocationic bichalcophenes are potent scavengers for

Table 5 Antioxidant activity assay (ABTS) of the tested bichalcophene compounds

\begin{tabular}{ll}
\hline Compound number control of ABTS & \% inhibition \\
\hline Ascorbic acid & 86.2 \\
Ia & 70.2 \\
Ib & 61.5 \\
Ic & 57.2 \\
Id & 64.3 \\
le & 61.8 \\
If & 54.3 \\
Ig & 52.3 \\
Ij & 56.0 \\
2a & 27.2 \\
2b & 19.8 \\
2c & 21.3 \\
$5 \mathrm{a}$ & 65.5 \\
$5 \mathrm{~b}$ & 60.3 \\
$5 \mathrm{c}$ & 66.5 \\
7 & 56.3 \\
\hline
\end{tabular}

Abbreviation: ABTS, 2,2'-azino-bis(3-ethylbenzthiazoline-6-sulfonic acid) diammonium salt. 


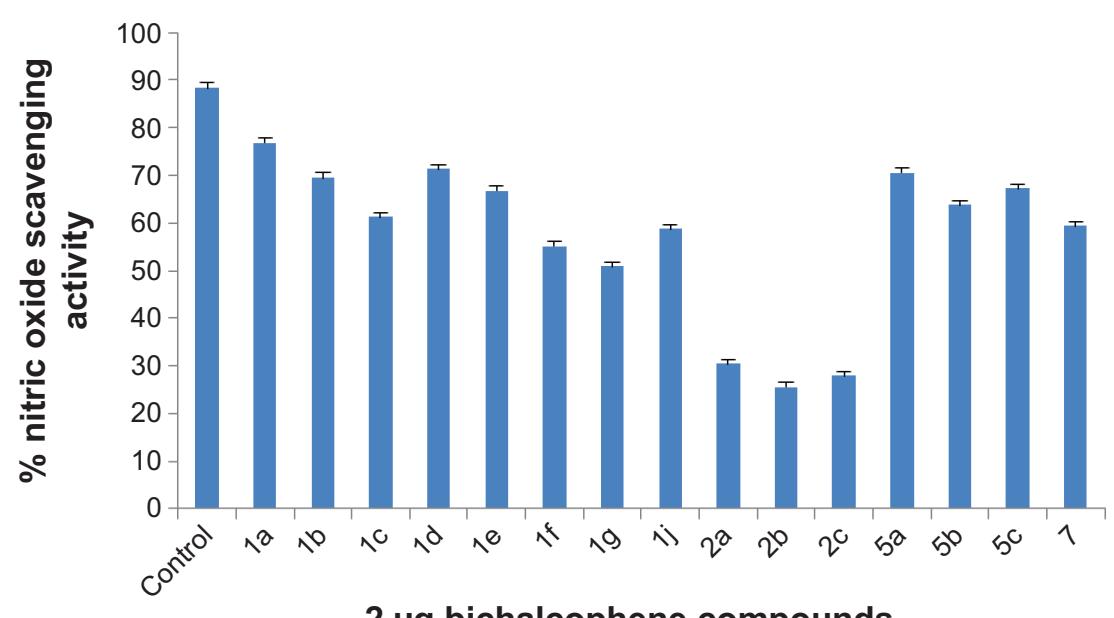

$2 \mu \mathrm{g}$ bichalcophene compounds

Figure 5 The nitric oxide scavenging activity of the tested bichalcophenes.

NO. Nitric oxide has been recognized to have a significant functional role in a diversity of physiological systems. Nitric oxide is a short-lived free radical, produced nonenzymatically, that causes damage in most biomolecules, including DNA and protein. Nitric oxide is involved in inflammation, cancer, and other pathological conditions. ${ }^{38}$ Nitric oxide generated from sodium nitroprusside reacts with oxygen to form nitrite. Therefore, monocationic bichalcophenes may inhibit nitrite formation by competing with oxygen to react with nitric oxide.

The presence of antioxidant substances in the antioxidant samples causes the reduction of the $\mathrm{Fe}^{3+} /$ ferricyanide complex to the ferrous form. Therefore, $\mathrm{Fe}^{2+}$ can be monitored by measuring the formation of Perl's Prussian blue at $700 \mathrm{~nm} .{ }^{39}$ The yellow color of the test solution changes to various shades of green and blue, depending on the reducing power of antioxidant samples. The reducing capacity of the bichalcophene compounds may serve as a significant indicator of their potential antioxidant activity. As shown in Figure 6, the bichalcophenes had effective and powerful reducing power, using the potassium ferricyanide reduction method, when compared against the control. For measurement of the reductive ability of the bichalcophenes, the $\mathrm{Fe}^{3+}-\mathrm{Fe}^{2+}$ transformation was investigated in the presence of the bichalcophene compounds. The results on reducing power demonstrate the electron donor properties of the monocationic bichalcophenes, thereby scavenging free radicals by forming stable adducts. The outcome of the redox reaction is to terminate radical chain reactions that may otherwise be very damaging.

The monocationic bichalcophenes exhibited effective antioxidant activity in the linoleic acid emulsion system. The

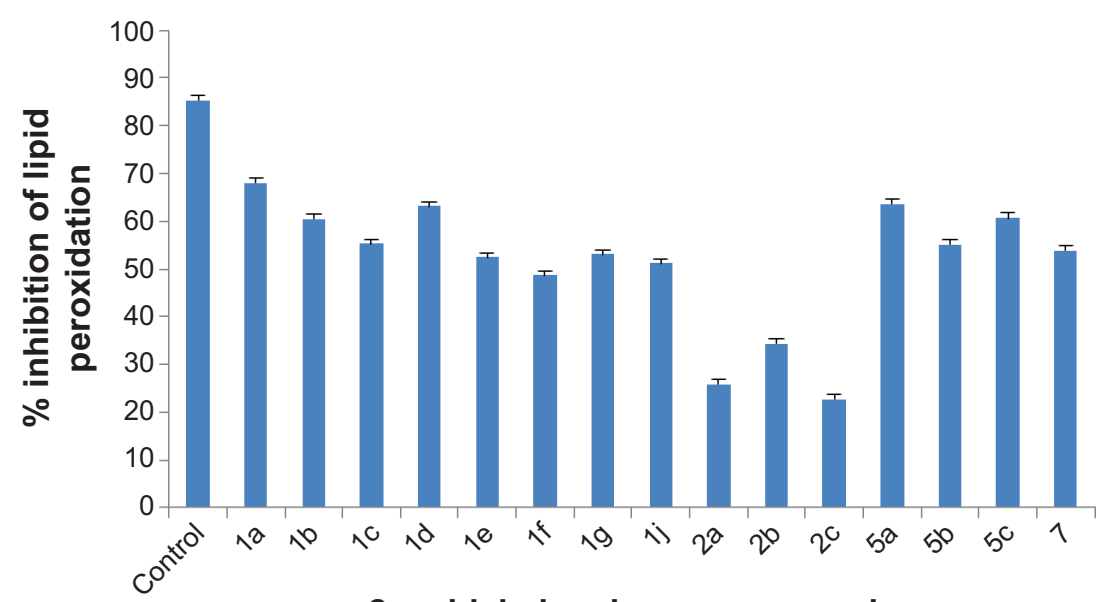

\section{$2 \mu \mathrm{g}$ bichalcophene compounds}

Figure 6 The activity of the tested bichalcophenes against lipid peroxidation. 
effect of $2 \mu \mathrm{g}$ of the bichalcophenes on the lipid peroxidation of linoleic acid emulsion is shown in Figure 6. The autoxidation of linoleic acid emulsion, without bichalcophenes or control, was accompanied by a rapid increase in peroxides. Consequently, these results clearly indicated that the monocationic bichalcophenes 1a, 5a, 1d, 5c, and 1b had good antioxidant activity, compared against the control.

\section{Conclusion}

Among the 12 monoamidine derivatives, the results of in vitro antiproliferative screening revealed that the bioisosteric replacement of a thiophene ring by a furan leads to a reduction in activity. Studying the effect of substitution on the phenyl ring of the bichalcophene derivatives, or its isosteric replacement by a pyridyl ring, has shown that the analogues having a pyridyl ring in place of the phenyl suffered a decrease in MPGI. In contrast, fluoro substitution on the phenyl ring led to a profound enhancement of the activity. The effect of positional isomerism on the antiproliferative effect of these derivatives was clearly observed. Interestingly, moving the amidine group from the phenyl to the thiophene side increased the activity. Among the nine types of cancer involved in the five-dose screen, non-small cell lung cancer cell lines were the most responsive to the antiproliferative effect of the tested compounds. The most active compounds were found to be $5 \mathrm{~b}, 5 \mathrm{c}, 1 \mathrm{~d}$, and 7 , displaying submicromolar $\mathrm{GI}_{50}$ values of $0.30 \mu \mathrm{M}, 0.52 \mu \mathrm{M}, 0.63 \mu \mathrm{M}$, and $0.95 \mu \mathrm{M}$, respectively. The monocationic bichalcophenes have demonstrated promising ability toward cleavage of genomic DNA. Moreover, antioxidant study results have indicated that this series of monocationic bichalcophenes have good antioxidant activity. In general, the monocationic bichalcophenes showed potent antiproliferative activity coupled with good antioxidant and nuclease mimic activities, which can, in part, be considered as the mechanism of action of these compounds. Given the potent in vitro anticancer activity of the monocationic bithiophene derivatives, further in vivo studies are merited, to clarify the real anticancer mechanism of this class of compounds.

\section{Acknowledgments}

This work was supported by the Deanship of Scientific Research, King Faisal University (Project Number 140058). The in vitro anticancer screening was done by the NCI, Betheseda, MD, USA.

\section{Disclosure}

The authors report no conflicts of interest in this work.

\section{References}

1. World Health Organization. Ten statistical highlights in global public health. In: World Health Statistics 2007. Geneva: World Health Organization; 2007.

2. Report sees 7.6 million cancer deaths worldwide in 2007. Chin Med J. 2008;121:26.

3. Ferlay J, Shin HR, Bray F, Forman D, Mathers C, Parkin DM. Estimates of worldwide burden of cancer in 2008: GLOBOCAN 2008. Int J Cancer. 2010;127(12):2893-2917.

4. American Cancer Society. Cancer facts and figures 2007. Atlanta, GA: American Cancer Society; 2007.

5. Kufe DW, Pollock RE, Weichselbaum RR, Bast RC Jr, Gansler TS, Holland JF, Frei E III, editors. Holland-Frei Cancer medicine. 6th ed. Hamilton, Canada: BC Decker; 2003.

6. Singh A, Shukla Y. Antitumor activity of diallyl sulfide in two-stage mouse skin model of carcinogenesis. Biomed Environ Sci. 1998;11(3):258-263.

7. Sundaram SG, Milner JA. Diallyl disulfide induces apoptosis of human colon tumor cells. Carcinogenesis 1996;17(4):669-673.

8. Kwon KB, Yoo SJ, Ryu DG, et al. Induction of apoptosis by diallyl disulfide through activation of caspase-3 in human leukemia HL-60 cells. Biochem Pharmacol. 2002;63(1):41-47.

9. Zempleni J, Mock DM. Biotin biochemistry and human requirements. J Nutr Biochem. 1999;10(3):128-138.

10. Ismail MA, El Bialy SA, Brun R, et al. Dicationic phenyl-2,2'bichalcophenes and analogues as antiprotozoal agents. Bioorg Med Chem. 2011;19(2):978-984.

11. Youssef MM, Al-Omair MA, Ismail MA. Synthesis, DNA affinity, and antimicrobial activity of 4-substituted phenyl-2,2'-bichalcophenes and aza-analogues. Med Chem Res. 2012;21(12):4074-4082.

12. Batista DG, Pacheco MG, Kumar A, et al. Biological, ultrastructural effect and subcellular localization of aromatic diamidines in Trypanosoma cruzi. Parasitology. 2010;137(2):251-259.

13. El-Sayed WM, Hussin WA, Ismail MA. Efficacy of two novel 2,2'bifurans to inhibit methicillin-resistant Staphylococcus aureus infection in male mice in comparison to vancomycin. Drug Des Devel Ther. 2012; 6:279-287.

14. Hudson JB, Harris L, Marles RJ, Arnason JT. The anti-HIV activities of photoactive terthiophenes. Photochem Photobiol. 1993;58(2):246-250.

15. Marles RJ, Hudson JB, Graham EA, et al. Structure-activity studies of photoactivated antiviral and cytotoxic tricyclic thiophenes. Photochem Photobiol. 1992;56(4):479-487.

16. Mazur S, Tanious FA, Ding D, et al. A thermodynamic and structural analysis of DNA minor-groove complex formation. J Mol Biol. 2000; 300(2):321-337.

17. White EW, Tanious F, Ismail MA, et al. Structure-specific recognition of quadruplex DNA by organic cations: influence of shape, substituents and charge. Biophys Chem. 2007;126(1-3):140-153.

18. Bailly C, Dassonneville L, Carrasco C, et al. Relationships between topoisomerase II inhibition, sequence-specificity and DNA binding mode of dicationic diphenylfuran derivatives. Anticancer Drug Des. 1999;14(1):47-60.

19. Wilson WD, Tanious F, Ding D, et al. Nucleic acid interactions of unfused aromatic cations: Evaluation of proposed minor-groove, majorgroove and intercalation binding modes. J Am Chem Soc. 1998;120(40): 10310-10321.

20. Liu Y, Kumar A, Depauw S, et al. Water-mediated binding of agents that target the DNA minor groove. J Am Chem Soc. 2011;133(26): 10171-10183.

21. Guerri A, Simpson IJ, Neidle S. Visualization of extensive water ribbons and network in a DNA minor-groove drug complex. Nucleic Acids Res. 1998;26(12):2873-2878.

22. Laughton CA, Tanious F, Nunn CM, Boykin DW, Wilson WD, Neidle SA. A crystallographic and spectroscopic study of the complex between d(CGCGAATTCGCG)2 and 2,5-bis(4-guanylphenyl)furan, an analogue of berenil. Structural origins of enhanced DNA-binding affinity. Biochemistry. 1996;35(18):5655-5661. 
23. Fitzgerald DJ, Anderson JN. Selective nucleosome disruption by drugs that bind in the minor groove of DNA. J Biol Chem. 1999;274(38): 27128-27138.

24. Dykstra CC, McClernon DR, Elwell LP, Tidwell RR. Selective inhibition of topoisomerases from Pneumocystis carinii compared with that of topoisomerases from mammalian cells. Antimicrob Agents Chemother. 1994;38(9):1890-1898.

25. Nhili R, Peixoto P, Depauw S, et al. Targeting the DNA-binding activity of the human ERG transcription factor using new heterocyclic dithiophene diamidines. Nucleic Acids Res. 2013;41(1): 125-138.

26. Munde M, Kumar A, Peixoto $\mathrm{P}$, et al. The unusual monomer recognition of guanine-containing mixed sequence DNA by a dithiophene heterocyclic diamidine. Biochemistry 2014;53(7):1218-1227.

27. Boschi D, Guglielmo S, Aiello S, Morace G, Borghi E, Fruttero R. Synthesis and in vitro antimicrobial activities of new (cyano-NNOazoxy)pyrazole derivatives. Bioorg Med Chem Lett. 2011;21(11): 3431-3434.

28. Hussin WA, Ismail MA, El-Sayed WM. Novel 4-substituted phenyl2,2'-bichalcophenes and aza-analogs as antibacterial agents: a structural activity relationship. Drug Des Devel Ther. 2013;7:185-193.

29. El-Sayed WM, Hussin WA. Antimutagenic and antioxidant activity of novel 4-substituted phenyl-2,2'-bichalcophenes and aza-analogues. Drug Des Devel Ther. 2013;7:73-81.

30. Ismail MA, Hussin WA, Alzahrani AM, El-Sayed WM. Evaluation of the biological activity of novel monocationic fluoroaryl-2,2'-bichalcophenes and their analogues. Drug Des Devel Ther. 2014;8:963-972.

31. Biffinger JC, Kim HW, DiMagno SG. The polar hydrophobicity of fluorinated compounds. Chembiochem. 2004;5(5):622-627.

32. Dimagno SG, Sun H. The strength of weak interactions: aromatic fluorine in drug design. Curr Top Med Chem. 2006;6(14):1473-1482.

33. Mallena S, Lee MP, Bailly C, et al. Thiophene-based diamidine forms a “super” AT binding minor groove agent. J Am Chem Soc. 2004;126(42): 13659-13669.

34. Ismail MA, Brun R, Easterbrook JD, Tanious FA, Wilson WD, Boykin DW. Synthesis and antiprotozoal activity of aza-analogues of furamidine. J Med Chem. 2003;46(22):4761-4769.
35. Nanjunda R, Musetti C, Kumar A, et al. Heterocyclic dications as a new class of telomeric G-quadruplex targeting agents. Curr Pharm Des. 2012;18(14):1934-1947.

36. Mancin F, Scrimin P, Tecilla P, Tonellato U. Artificial metallonucleases. Chem Commun (Camb). 2005;(20):2540-2548.

37. He J, Sun J, Mao ZW, Ji LN, Sun H. Phosphodiester hydrolysis and specific DNA binding and cleavage promoted by guanidinium-functionalized zinc complexes. J Inorg Biochem. 2009;103(5):851-858.

38. Moncada S, Palmer RM, Higgs EA. Nitric oxide: physiology, pathophysiology, and pharmacology. Pharmacol Rev. 1991;43(2):109-142.

39. Chung YC, Chang CT, Chao WW, Lin CF, Chou ST. Antioxidant activity and safety of the $50 \%$ ethanolic extract from red bean fermented by Bacillus subtilus IMR-NK1. J Agr Food Chem. 2002;50:2454-2458.

40. Skehan P, Storeng R, Scudiero D, et al. New colorimetric cytotoxicity assay for anticancer-drug screening. J Natl Cancer Inst. 1990;82(13): 1107-1112.

41. McCaffrey TA, Agarwal LA, Weksler BB. A rapid fluorometric DNA assay for the measurement of cell density and proliferation in vitro. In Vitro Cell Dev Biol. 1988;24(3):247-252.

42. Monks A, Scudiero D, Skehan P, et al. Feasibility of a high-flux anticancer drug screen using a diverse panel of cultured human tumor cell lines. J Natl Cancer Inst. 1991;83(11):757-766.

43. Youssef MM, Al-Omair MA. Cloning, purification, characterization and immobilization of L-asparaginase II from E. coli W3110. Asian J Biochem. 2008;3(6):337-350.

44. Re R, Pellegrini N, Proteggente A, Pannala A, Yang M, Rice-Evans C. Antioxidant activity applying an improved ABTS radical cation decolorization assay. Free Radic Bio Med. 1999;26(9-10):1231-1237.

45. Green LC, Wagner DA, Glogowski J, Skipper PL, Wishnok JS, Tannenbaum SR. Analysis of nitrate, nitrite, and [15N]nitrate in biological fluids. Anal Biochem. 1982;126(1):131-138.

46. Sreejayan N, Rao MN. Nitric oxide scavenging by curcuminoids. J Pharm Pharmacol. 1997;49(1):105-107.

47. Gülçin İ, Daştan A. Synthesis of dimeric phenol derivatives and determination of in vitro antioxidant and radical scavenging activities. J Enzyme Inhib Med Chem. 2007;22(6):685-695.
Drug Design, Development and Therapy

\section{Publish your work in this journal}

Drug Design, Development and Therapy is an international, peerreviewed open-access journal that spans the spectrum of drug design and development through to clinical applications. Clinical outcomes, patient safety, and programs for the development and effective, safe, and sustained use of medicines are a feature of the journal, which

\section{Dovepress}

has also been accepted for indexing on PubMed Central. The manuscript management system is completely online and includes a very quick and fair peer-review system, which is all easy to use. Visit http://www.dovepress.com/testimonials.php to read real quotes from published authors. 